Industrial-Strength Denial 



\section{Industrial-Strength Denial}

EIGHT STORIES OF CORPORATIONS DEFENDING THE INDEFENSIBLE, FROM THE SLAVE TRADE

TO CLIMATE CHANGE

\section{Barbara Freese}

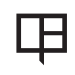

UNIVERSITY OF CALIFORNIA PRESS 
The publisher and the University of California Press Foundation gratefully acknowledge the generous support of the Anne G. Lipow Endowment Fund in Social Justice and Human Rights.

University of California Press

Oakland, California

(C) 2020 by Barbara Freese

Cataloging-in-Publication Data is on file at the Library of Congress.

ISBN 9780520296282 (cloth)

ISBN 9780520968851 (ebook)

Manufactured in the United States of America

$\begin{array}{llllllllll}29 & 28 & 27 & 26 & 25 & 24 & 23 & 22 & 21 & 20\end{array}$

$\begin{array}{llllllllll}10 & 9 & 8 & 7 & 6 & 5 & 4 & 3 & 2 & 1\end{array}$ 